\title{
Reseña del libro: No eran trabajadoras, sólo mujeres. Onintza Irureta Azkune. Fundación Manu Robles-Arangiz ${ }^{1}$
}

Book Review No eran trabajadoras, sólo mujeres. Onintza Irureta Azkune. Fundación Manu Robles- Aranguiz

Eva Bermúdez Figueroa

Universidad de Cádiz

eva.bermudez@uca.es

\section{Reseña de un libro}

La obra “No eran trabajadoras, sólo mujeres", escrita por Onintza ilureta Azkune ha sido publicada por la Fundación Manu Robles- Instituto Arangiz. La Fundación, impulsada por el sindicato ELA (Eusko Langileen Alkartasuna) tiene como meta principal el desarrollo y la divulgación de los valores del sindicalismo, especialmente el sindicalismo vasco, objetivo que se materializa con esta reciente publicación. En ella, la periodista Onintza Irureta narra, a través del relato de algunas de las mujeres protagonistas, el largo periodo de lucha laboral que mantuvieron las trabajadoras de centros de mayores entre 2017 y 2018 en Vizcaya por la firma del quinto convenio colectivo del sector. Fue una huelga de 378 días en la que las trabajadoras de residencias de mayores buscaban mejorar sus condiciones laborales y dignificar su profesión. El libro aparece prologado por Irantzu Varela, conocida periodista y militante feminista.

El relato de Irureta presenta la novedad de la carga emocional, personal y afectiva, de una lucha sindical sin tregua de uno de los sectores más castigados, infravalorados y peor remunerados en el espectro de ocupaciones donde se acumula el empleo de las mujeres. Esta aportación, reforzada aún si cabe por la excepcionalidad del momento actual, que pone de manifiesto la imperiosa necesidad y dependencia de la sociedad y de todo el sistema productivo, de una mayoría de mujeres en sectores del cuidado, como el sanitario, la limpieza y la ayuda a personas dependientes, hace de este libro un alegato reclamando la vital y suma importancia del cuidado de las mujeres, y las necesarias condiciones de un empleo decente. Exceptuando el empleo doméstico y limpieza, las mujeres trabajadoras en el cuidado de

${ }^{1}$ Recibido: 19/05/2017 Evaluado: 23/06/2017 Aceptado: 25/06/2017 
mayores forman parte de los últimos eslabones en la cadena social y laboral. Junto con ellas, la mayor proporción estimada de empleo invisible a la sociedad general, y a la economía en particular, en especial en la sumergida (Cebrián López, 2015; Aguado, 2018). Así mismo, se pone de manifiesto la ineludible e imprescindible necesidad de la lucha sindical como colectivo de trabajadoras, para la consecución de condiciones dignas en el trabajo. Sumar a la literatura sindical y de la acción colectiva, las experiencias reales y en algunos casos descarnada de su situación laboral y familiar, aporta un valor novedoso y poco común a las referencias básicas de la literatura de la acción sindical, mayoritariamente aséptica y tradicionalmente alejada de las vivencias personales en los aspectos más emocionales. Curiosamente, esta sensibilidad forma parte de las características estereotipadas femeninas, también distantes de la literatura en las relaciones laborales.

No eran trabajadoras, solo mujeres. Para ser considerada trabajadora, hay que subir un escalón. Así funciona la escala social. Ser mujer implica una menor consideración social, y conlleva la responsabilidad del Cuidado per se, en mayúsculas, y no se remunera a las mujeres por ser. No eran trabajadoras, sólo mujeres, desvela que estas mujeres no fueron espectadoras secundarias de las luchas de otros, sino las protagonistas, las agentes del cambio vital y laboral. Con este acertado título, Irureta resume a la perfección los valores patriarcales, que se reflejan en un mercado laboral más precario para las mujeres, y cuyas relaciones laborales transmiten el sesgo de infravaloración del trabajo de cuidados proporcionados por las mujeres, sobre el que descansa el sistema mismo. El trabajo de cuidados y su justa valoración y medida, es una de las mayores reivindicaciones feministas, y se ven encarnadas en estas mujeres trabajadoras.

La obra cuenta con tres partes diferenciadas a través de las cuales la autora enmarca la situación del sector de trabajadoras de residencias de mayores en Vizcaya en unos años duros de recortes presupuestarios en derechos sociales y salud, y la gestión del conflicto por parte de los sindicatos y la acción de las trabajadoras.

Si bien la literatura sobre las relaciones laborales es muy abundante a nivel estatal, así como en el País Vasco (Elorrieta, 2017; Las Heras, 2018), se hace difícil encontrar obras específicas sobre el papel desempeñado por las mujeres en la acción colectiva. Encontrar obras sobre de la defensa de los derechos laborales con mujeres como protagonistas, es complicado, salvo excepciones (Bermúdez y Roca, 2018). Con esta obra, Irureta viene a completar una parte del vacío existente, fundamentalmente a nivel académico, sobre la lucha de las mujeres de clase trabajadora.

Enmarcada la obra en el ámbito de las relaciones laborales y del sindicalismo feminista, la autora no solamente analiza y sintetiza las consecuciones laborales por la firma de convenios del sector y la implicación de las trabajadoras. Va más allá, ya que pone en valor y visibiliza las experiencias y percepciones de estas mujeres, que narran en primera persona sus procesos vitales y laborales, que les avocan a mantener un largo y doloroso conflicto colectivo. Es el relato de la gestación y desarrollo de un proceso de empoderamiento personal y colectivo de estas mujeres, que termina por vencer al individualismo debilitador de los derechos laborales y a la razón patriarcal. 
Los frentes patriarcales a los que se enfrentan estas mujeres son varios. En primer lugar, porque se trata de un sector eminentemente feminizado, donde la mayoría de las trabajadoras son mujeres. En segundo lugar, porque los empleadores -específicamente en masculino- son mayoritariamente hombres, y detentan los recursos de poder en las negociaciones, donde suelen ser los interlocutores válidos. Y, en tercer lugar, en un ámbito de estudio como la acción social o las relaciones laborales, donde los hombres han sido la medida de todas las cosas y el modelo universal (trabajador-obrero industrial-blanco-sustentador principal) como perfil de sindicalista, Irureta sitúa a las gerocultoras como protagonistas de una acción sindical valiente, decidida, sorora, y persistente. Tanto, como para dignificar y hacer valer su trabajo, hasta entonces infravalorado social, laboral y económicamente. Esta dignificación pasa por la mención, la palabra, el nombre, el lenguaje y su sentido real y simbólico: son gerocultoras, no cuidadoras. La primera parte hace una narración basada en la evolución de la negociación colectiva por parte de los sindicatos, fundamentalmente ELA, desde 2002 en el sector de residencias de mayores y sus consecuciones, que van generando autoconfianza en un determinado grupo de mujeres más implicadas. La implicación de las trabajadoras en el conflicto es asimétrica al principio y se desatan los temores al despido- - al acoso laboral y las represalias como se relata en el caso de Marina, trabajadora de Sanitas. Así uno de sus apartados, "Un dinerito extra para ir de vacaciones", complementario al de su marido -por tanto, prescindible y secundario,” ya sabes, para los gastos...”- es la forma en que uno de los empleadores califica al salario de una trabajadora cuando reclama sus derechos. A lo largo del texto se encuentran numerosas referencias a este tipo de comentarios, tan frecuentes en la vida de las trabajadoras.

La segunda parte "La Lucha en palabras en imágenes” está formada por una galería visual de fotografías tomadas en los distintos momentos del conflicto y las manifestaciones, en las que aparecen las trabajadoras. El potente discurso visual que emana del capítulo, prepara y refuerza el relato posterior, de las historias de vida de las mujeres protagonistas. En él se recogen noticias de prensa y se hace un seguimiento del avance e impacto del conflicto colectivo. Las fotografías que atestiguan las declaraciones a la prensa, las concentraciones, y las manifestaciones. Estas imágenes están impregnadas de emocionalidad, representando una sensibilidad y exteriorización de emociones que no puede dejar indiferente a quien las ve. La fuerza que le imprimen a la narración las fotografías de las mujeres, así como la poesía escrita por una de ellas en los momentos más críticos del conflicto, generan en este libro un poderoso vínculo entre la sensibilidad y las emociones experimentadas por las trabajadoras en la larga lucha, con la acción social misma. Se recogen en estas imágenes la indignación, la paciencia, el dolor, la ira, la alegría, las lágrimas compartidas, que evidencian el proceso personal profundo e intenso que han vivido estas mujeres. Así, este libro contribuye al acercamiento entre la emoción y la acción social, la consecución de grandes logros personales y colectivos, el empoderamiento de unas mujeres conscientes de sus derechos y de la importancia y necesidad de su labor y su militancia.

Estos logros personales son relatados en la tercera parte del libro en forma de historias de vida contadas por las trabajadoras. A pesar de las diferencias generacionales o de momentos vitales, estas mujeres brindan generosamente sus vivencias, sus percepciones del proceso que ellas viven como emancipador, del que salen victoriosas, de la defensa colectiva de sus trabajos frente a la precariedad laboral, y de la creación de lazos con las compañeras. 
Los relatos de Ainoha, Maribel, Marina, Verónica y Lara, Aitziber, Kontxi y Marisol, son la confrontación con la realidad de las teorías de la acción sindical, del derecho del trabajo, del empoderamiento a través del conflicto, del reconocimiento del poder colectivo... Son las caras y los cuerpos de mujeres que han cuidado y cuidan a nuestros mayores:" somos sus manos, sus piernas, y también les escuchamos” (Góngora p.106). En todas sus historias se expone la precariedad laboral a la que han estado sometidas las trabajadoras de residencias, con trabajo destajo y exceso de carga, sin medios materiales suficientes, sin un buen convenio colectivo que las respaldara legalmente de las arbitrariedades de la patronal, y en la mayoría se relatan escenas de machismo y de infravaloración del trabajo realizado por estas mujeres. Precariedad no solo económica por los bajos salarios, dados los esfuerzos físicos requeridos, sino que "una de las consecuciones de la huelga ha sido el derecho al descanso e ir al baño" (p.108).

En definitiva, este volumen es una aportación práctica valiosa sobre la implicación de las mujeres en la acción sindical, el proceso de toma de conciencia social y laboral de explotación y la necesaria acción social. Representa así mismo una ruptura con la hegemonía masculina en el mundo sindical y su reflejo en la literatura. Al mismo tiempo, es una muestra de todo un emocionario que se vincula a los procesos comunitarios de empoderamiento social y feminista, tan alejados normalmente de los referentes sindicales habituales, destacando la capacidad de agencia personal y colectiva desde el feminismo en la defensa de los derechos laborales.

\section{Referencias}

Aguado, E. (2018). 'Segregación ocupacional: una mirada crítica a la participación tamizada de las mujeres en el empleo’, Gaceta Sindical. Reflexión y debate, 31, pp. 285-308.

Bermúdez Figueroa, E., y Roca Martínez, B. (2019). Participación de mujeres en el movimiento sindical. Análisis desde la perspectiva de los recursos de poder. Sociología Del Trabajo, 53-72. https://doi.org/10.5209/stra.66435

Cebrián López, I. (2015). Tiempo cotizado, ingresos salariales y sus consecuencias para las pensiones: diferencias por género al final de la vida laboral. Cuadernos de Relaciones Laborales, 33(2), 311-328. https://doi.org/10.5209/rev_crla.2015.v33.n2.50318

Elorrieta, J. (2017). Una mirada sindical contracorriente. Clase, territorio y nuevas alianzas. Barcelona: Icaria.

Las Heras, J. (2019). To sign or not to sign? Union strategies towards provincial metal sector agreements in the Catalan and Basque automotive industries. European Journal of Industrial Relations 25(2), 181-200. 